УДК 624.131

\title{
РАЙОНИРОВАНИЕ УЧАСТКОВ СТРОИТЕЛЬСТВА ПРУДОВ-ОТСТОЙНИКОВ ЭЛЬГИНСКОГО КАМЕННОУГОЛЬНОГО МЕСТОРОЖДЕНИЯ В ЯКУТИИ
}

\author{
Строкова Людмила Александровна, \\ sla@tpu.ru \\ Национальный исследовательский Томский политехнический университет, \\ Россия, 634050, г. Томск, пр. Ленина, 30.
}

\begin{abstract}
Актуальность исследования обусловлена стремительным ростом геологоразведочной и производственной деятельности в районах вечной мерзлоты в России за последние сорок лет. В статье приведена характеристика площадок размещения прудов-отстойников Эльгинского горно-обогатительного комбината в Республике Саха (Якутия). Инженерно-геологическая оценка территории необходима для того, чтобы поддержать процесс принятия решений по размещению сооружений, а также для того, чтобы строительство объектов осуществлялось с меньшим отрицательным воздействием на окружающую среду, сопровождалось снижением опасности и ущерба как для строительства, так и в целом для общества и экономики.

Целью данного исследования является установление уязвимости территории к техногенному загрязнению на основе изучения инженерно-геологических условий площадок размещения прудов-отстойников.

объектом исследования является геологическая среда площадок размещения прудов-отстойников. Рассмотрены основные природные компоненты, влияющие на планирование и развитие землепользования: литологический состав; геоморфологические и тектонические условия; физико-механические свойства пород, гидрологические, гидрогеологические и мерзлотные условия района.

Методы. Данное исследование включает в себя краткий обзор соответствующей литературы; анализ информации, полученной из фондов изыскательской компании; определение признаков и методики районирования. Все информационнье слои о природной среде обрабатывались, затем объединялись для получения единой инженерно-геологической карты.

Результаты. Приведена характеристика инженерно-геологических условий площадок прудов-отстойников Эльгинского угольного комплекса в Республике Саха (Якутия). Разработана карта инженерно-геологического районирования площадок по уязвимости (сильной, средней, слабой, незначительной) геологической среды к техногенному загрязнению.
\end{abstract}

\section{Ключевые слова:}

Пруд-отстойник, карьерная добыча, грунт, уголь, геологический процесс, физико-механические свойства, районирование, уязвимость.

\section{Введение}

Реализация крупных энергопроектов в восточных районах России повысила значимость инженерногеологической оценки этих территорий, а именно, выявление уже на ранних стадиях проектирования тех факторов геологической среды, которые обеспечивают ее устойчивость к техногенной нагрузке, способствуя предотвращению экономического, социального и финансового ущерба [1-6].

Одним из крупнейших проектов, реализуемых в последние годы на Дальнем Востоке, является создание Эльгинского угольного комплекса на основе крупнейшего по запасам и качеству Эльгинского месторождения коксующихся и энергетических каменных углей, расположенного в юго-восточной части Республики Саха (Якутия). Проектная мощность угольного разреза составляет 30 млн т угля в год. Запасы угля составляют 2,078 млрд т, срок службы разреза оценивается в 96 лет. Реализация объекта приведет к трансформации геологической среды: изменению рельефа, образованию значительных массивов техногенных отложений, перестройке гидрографической сети, изменению состава и режима поверхностных и подземных вод, геологических процессов [7-12].

Оценке инженерно-геологических условий при реализации различных проектов в сложных условиях, в т. ч. в криолитозоне, посвящены работы [4, 14-21]. Многочисленные исследования направлены на изуче- ние влияния земляных работ на поверхностные и подземные воды [7-10], оценку состояния окружающей среды с помощью ГИС-технологий [22-38]. Одним из перспективных методов оценки устойчивости геологической среды при освоении является типологическое инженерно-геологическое районирование территории, технология выполнения которого подробно изложена в работе В.Т Трофимова и Н.С. Красиловой [13]. Этот метод позволяет решать много задач по рациональному использованию территорий, поэтому давно и широко используется в мире.

Целью данного исследования является описание инженерно-геологических условий площадок размещения прудов-отстойников и их районирование по уязвимости геологической среды к техногенному загрязнению.

\section{Характеристика объекта}

По административному делению район работ расположен в Нерюнгринском районе Республики Саха (Якутия), в 400 км на восток от г. Нерюнгри. Месторождение расположено на юго-восточной окраине Алданского нагорья, в пределах Токинской впадины, являющейся составной частью Южно-Якутского каменноугольного бассейна.

Южно-Якутский каменноугольный бассейн является природно-технической системой (ПТС) регионального уровня. ПТС Эльгинского ГОКа относится к системе локального уровня, включающей в себя эле- 
ментарные ПТС: карьер, обогатительная фабрика, отвалы вскрышных пород, гидротехнические, транспортные сооружения и др. Работы на Эльгинском разрезе приведут к образованию полости в земной коре объемом более 800 млн м ${ }^{3}$ и площадью несколько десятков км². Отвалы вскрышных пород будут представлены тремя внешними отвалами общим объемом 833,5 млн м³ ${ }^{3}$, и внутренним отвалом объемом 579,7 млн м ${ }^{3}$ [7]. Гидротехнические сооружения представляют собой пруды-отстойники (№ 1-4, К, рис. 1), под которые отведено порядка 80 га, крупнейшим объектом среди них станет пруд-отстойник карьерных вод (№ 5) площадью 34,6 га. Наполнение данного объекта произойдет после 2021-2023 гг. Основное преобразование природных комплексов при строительстве объектов I очереди связано с частичным перестроением гидрографической сети бассейна р. Укикит, увеличением мутности воды на определенных участках р. Укикит и её притоков. Прудыотстойники поверхностного стока и карьерных вод располагаются на слабонаклонных участках с отметками поверхности 852-947 м.

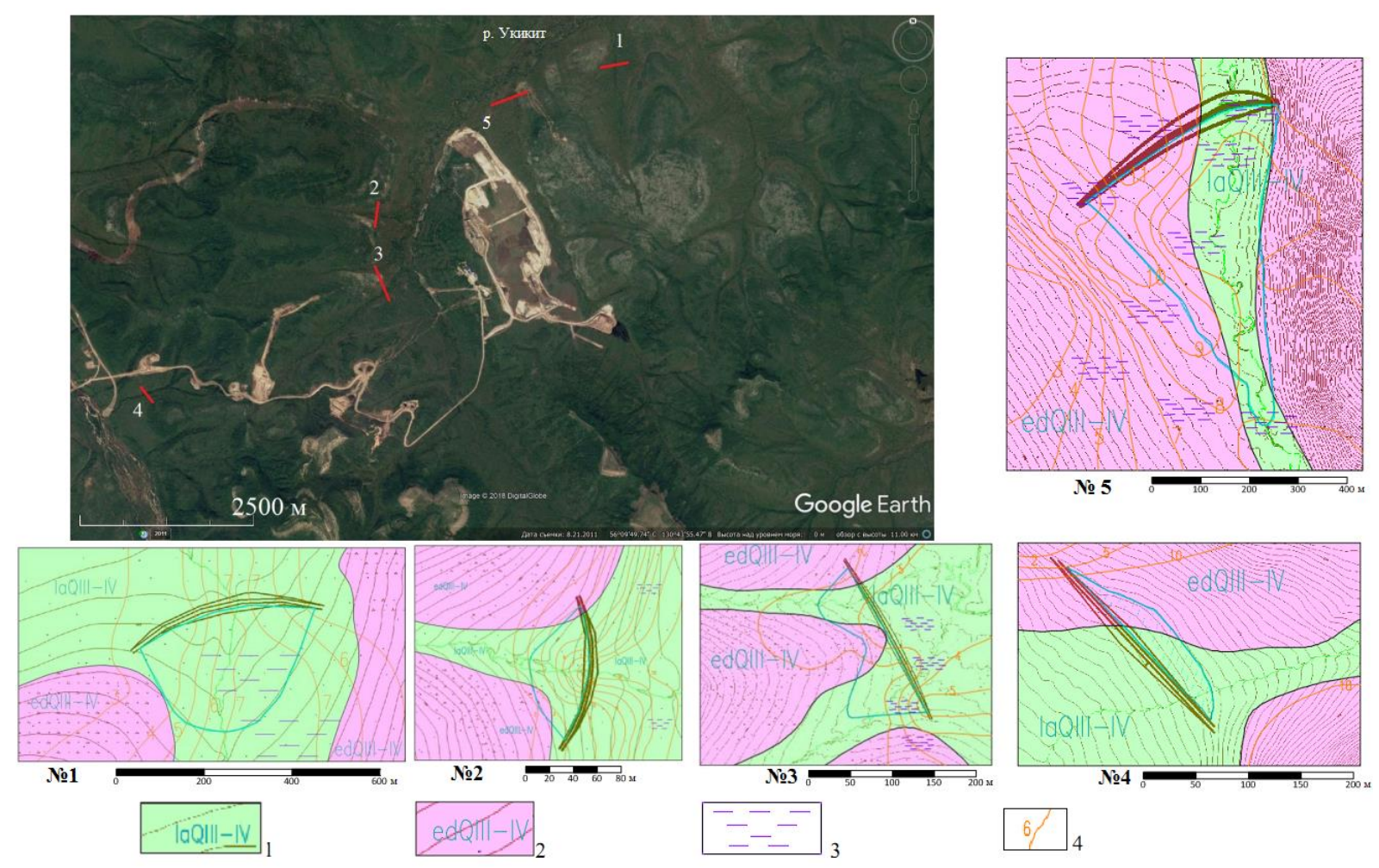

Рис. 1. Местоположение изученных участков на снимке Гугл; схематические геологические карты прудовнакопителей. Условные обозначения: 1 - озерно-аллювиальные отложения; 2 - элювиально-делювиальные отложения; 3 - заболоченность; 4 -изолинии глубины залегания кровли скальных пород

Fig. 1. Location of the studied areas in the Google image; schematic geological maps of settling ponds. Symbols: 1 lacustrine-alluvial deposits; 2 -eluvial-deluvial deposits; 3 -wetlands; 4 -isolines of the depth of the bedrocks

В тектоническом строении территории выделяется четыре структурных этажа. Нижний структурный этаж представляет собой жесткий кристаллический фундамент, сложенный дислоцированными архейскими метаморфитами, насыщенными гранитоидами позднеархейско-протерозойского возраста. Второй платформенный чехол, сложен рифейскими терригенными и венд-кембрийскими, преимущественно карбонатными отложениями и нижнеюрскими терригенными породами. Третий структурный этаж представлен активизационными структурами мезозойского возраста Четвертый соответствует этапу неотектонического развития, выраженного глубоким расчленением рельефа, сейсмической активностью района и проявлением трахибазальтового магматизма [39]. По материалам инженерно-геофизических изысканий территория относится к семибалльной сейсмической зоне.
В геологическом строении района принимают участие верхнеюрские отложения нерюнгриканской свиты $\left(\mathrm{J}_{3} \mathrm{nr}\right)$, перекрытые с поверхности верхнечетвертичными и современными отложениями озерно-аллювиального $\left(\mathrm{laQ}_{\text {III-IV }}\right.$ ) и элювиально-делювиального (edQ зисов [39].

Верхнечетвертичные и современные отложения озерно-аллювиального генезиса (laQ $\mathrm{III-IV})$ имеют широкое распространение по площади, приурочены к долинам водотоков (рис. 1). На площадках прудовотстойников № $1,3,5$ первый от поверхности слой с мощностью до 0,4 ...1,8 м представлен слабо-, среднезаторфованными песками пылеватыми, супесями и суглинками с дресвой, дресвяными, дресвяными и щебенистыми грунтами с песчаным, супесчаным и суглинистым заполнителем, а также торфом бурым среднеразложившимся, подстилается отложениями 
преимущественно аллювиального генезиса. Аллювиальные отложения также залегают первыми от поверхности в центральной части площадок прудов накопителей № 2 и 4. Отложения представлены песками, супесью и суглинками с гравием, гравелистыми, галечниковыми и гравийными грунтами с песчаным, супесчаным и суглинистым заполнителем, мощностью 0,5...10,2 м. Обломочный материал представлен осадочными, магматическими и метаморфическими породами, плохой, средней и хорошей степени окатанности. Благоприятные условия для образования озерно-аллювиальных отложений обусловлены широким распространением многолетней мерзлоты, боковой эрозией и блужданием русел рек в долинах.

Верхнечетвертичные и современные отложения элювиально-делювиального генезиса (ed $\left.Q_{I I I-I V}\right)$ имеют широкое распространение, вскрыты с поверхности на склонах водотоков мощностью $0,9 \ldots 3,7$ м. Отложения представлены песками пылеватыми, супесями и суглинками с дресвой, дресвяными, а также дресвяными и щебенистыми грунтами с песчаным, супесчаным и суглинистым заполнителем от 10 до $49 \%$. Обломочный материал представлен осадочными породами различной прочности.

Верхнеюрские отложения нерюнгриканской сви$m b l\left(J_{3} n r\right)$ имеют повсеместное распространение, залегают под четвертичными отложениями с глубины $0,5 \ldots 4$ м, вскрытой мощностью 0,5 ..55,0 м. Породы представлены песчаниками и алевролитами различной прочности с пластами и пропластками углей.

В ходе проведенных изысканий 2009-2010 гг. [41] в пределах района освоения Эльгинского угольного месторождения выделены инженерно-геологические элементы (ИГЭ):

ИГЭ-1 Торф бурый, коричневый, среднеразложившийся, имеет локальное распространение по площади, вскрыт с поверхности под почвеннорастительным слоем, мощностью $0,3 \ldots 0,7$ м. На период изысканий грунт находился в мерзлом состоянии, массивной и слоистой криогенной текстуры, при оттаивании средней степени водонасыщения и насыщенный водой.

ИГЭ-2 Суглинок заторфованный бурый, коричневый, серо-коричневый, темно-серый, имеет повсеместное распространение по площади, вскрыт с поверхности под почвенно-растительным слоем и с глубины 3,6м, мощностью $0,7 \ldots 2,4$ м.

ИГЭ-4 Супесь с дресвой от 1 до 24 \%, бурая, темно-серая, серая, темно-коричневая. Грунт имеет повсеместное распространение по площади, вскрыт с поверхности под почвенно-растительным слоем и с глубины $0,5 \ldots 2,5$ м, мощностью $0,7 \ldots 3,9$ м. Обломочный материал представлен песчаником мелкозернистым, от малой до средней прочности.

ИГЭ-7 Дресвяный грунт с супесчаным заполнителем до $33 . .49 \%$, имеет повсеместное распространение по площади, вскрыт как с поверхности под почвеннорастительным слоем, так и с глубины 1,0...2,0 м, мощностью 1,2...3,4 м. Обломочный материал представлен алевролитом и песчаником мелкозернистым, серым, малой, средней прочности и прочным.
ИГЭ-9 Супесь гравелистая зеленовато-серого, серовато-коричневого и темно-серого цвета. Грунт имеет ограниченное распространение по площади, вскрыт на глубине 0,6-1,6 м, мощностью 1,6...2,7 м. Обломочный материал представлен магматическими, метаморфическими и осадочными породами различной степени окатанности, от низкой до малой прочности.

ИГЭ-9м Супесь гравелистая твердомерзлая зеленовато-серая, серовато-коричневая и темно-серая. Грунт имеет повсеместное распространение по площади, вскрыт с глубины 2,9...7,0 м, вскрытой мощностью 1,8...5,9 м. Обломочный материал представлен магматическими, метаморфическими и осадочными породами различной степени окатанности, от низкой до малой прочности.

ИГЭ-11 Песок средней крупности серый, зеленовато-серый, желто-коричневый и темно-серый. Грунт имеет ограниченное распространение по площади. Вскрыт с поверхности под почвенно-растительным слоем и с глубины 1,0..3,3 м, мощностью 0,5 ..1,8 м.

ИГЭ-11м Песок средней крупности, твердомерзлый серый, зеленовато-серый, желто-коричневый и темно-серый. Грунт имеет ограниченное распространение по площади. Вскрыт с глубины 2,6..5,8 м, мощностью $1,1 \ldots 2,4$ м.

ИГЭ-12м Песок гравелистый твердомерзлый серокоричневый, зеленовато-коричневый, имеет ограниченное распространение по площади, вскрыт с глубины 1,5 ..5,0 м, мощностью 1,4...1,5 м. Обломочный материал представлен магматическими, метаморфическими и осадочными породами различной степени окатанности, от низкой прочности до малой.

ИГЭ-13 Галечниковый грунт с супесчаным заполнителем до $32 \ldots 49$ \% коричневого и коричневатосерого цвета. Обломочный материал представлен магматическими, метаморфическими и осадочными породами различной степени окатанности, от низкой прочности до малой. Грунт имеет локальное распространение по площади, вскрыт с глубины 1,9 м, мощностью 2,1 м.

ИГЭ-13м Галечниковый грунт с супесчаным заполнителем, твердомерзлый. Заполнитель коричневато-серого и коричневого цвета до $31 \ldots 43 \%$. Обломочный материал представлен магматическими, метаморфическими и осадочными породами различной степени окатанности, от низкой прочности до малой. Грунт имеет локальное распространение по площади, вскрыт с глубины 2,0..5,0 м, вскрытой мощностью $1,3 \ldots 5,0 \mathrm{~m}$.

Обобщенные характеристики основных физикомеханических свойств грунтов приведены в работе [40].

В геокриологическом отношении территория расположена в зоне сплошного развития многолетнемерзлых пород. Граница сезонного оттаивания составляет четыре метра. Грунты имеют массивную и слоистую криогенную текстуру. Скальные грунты находится в морозном состоянии. На глубине годовых нулевых амплитуд температура изменяется от минус 0,1 до минус $1,5^{\circ} \mathrm{C}$. 
Гидрогеологические условия территории характеризуются развитием надмерзлотных грунтовых вод, вскрытых локально - только на площадке размещения пруда-отстойника № 3 в трех шурфах на глубине $1 . .2$ м. Водовмещающими грунтами являются щебенистые, галечниковые грунты с супесчаным заполнителем и алевролиты «рухляки». Питание грунтовых вод происходит в основном за счёт инфильтрации атмосферных осадков и оттаивания сезонномёрзлых грунтов, водоупором служат вечномерзлые грунты [40]. С прекращением питания атмосферными осадками, наступлением отрицательных температур воздуха, перемерзанием русел водотоков надмерзлотный водоносный горизонт истощается, сокращается и к весне в основном прекращает свое существование. В местах отсутствия плотных мерзлых пород вода по трещинам свободно фильтруется вниз, пополняя запасы нижележащего комплекса пород.

Рельеф территории относится к эрозионноденудационному типу пологих и средней крутизны склонов плато на осадочных породах юры. Аккумулятивный тип рельефа приурочен к аллювиальным поймам рек Ундыткан, Укикит, Эльга. По рекам Алгома, Ундыткан и Эльга встречены моренные поверхности муруктинского оледенения. В месте слияния p. Ундыткан в р. Ундытын встречены моренные поверхности сартанского и муруктинского оледенений. Основные морфометрические параметры рельефа, такие как абсолютные отметки, уклон и экспозиция склонов (рис. 2), получены по цифровой модели рельефа SRTM (Shuttle Radar Topography Mission), загруженной с сайта USGS Earthexplorer. Именно с этими параметрами связан поверхностный сток и дренирование территории, ее теплообеспеченность. Местоположение прудов-отстойников приведено на рис. 2, б.

В целом инженерно-геологические условия района являются достаточно сложными в связи с высокой сейсмической активностью района, наличием многолетней мерзлоты и таких геологических процессов, как поверхностное заболачивание площадки, морозное выпучивание каменного материала на склонах водоразделов, морозное пучение несвязных грунтов в зимний период и присутствие в разрезе сильнотрещиноватых углей, алевролитов и песчаников «рухляков».
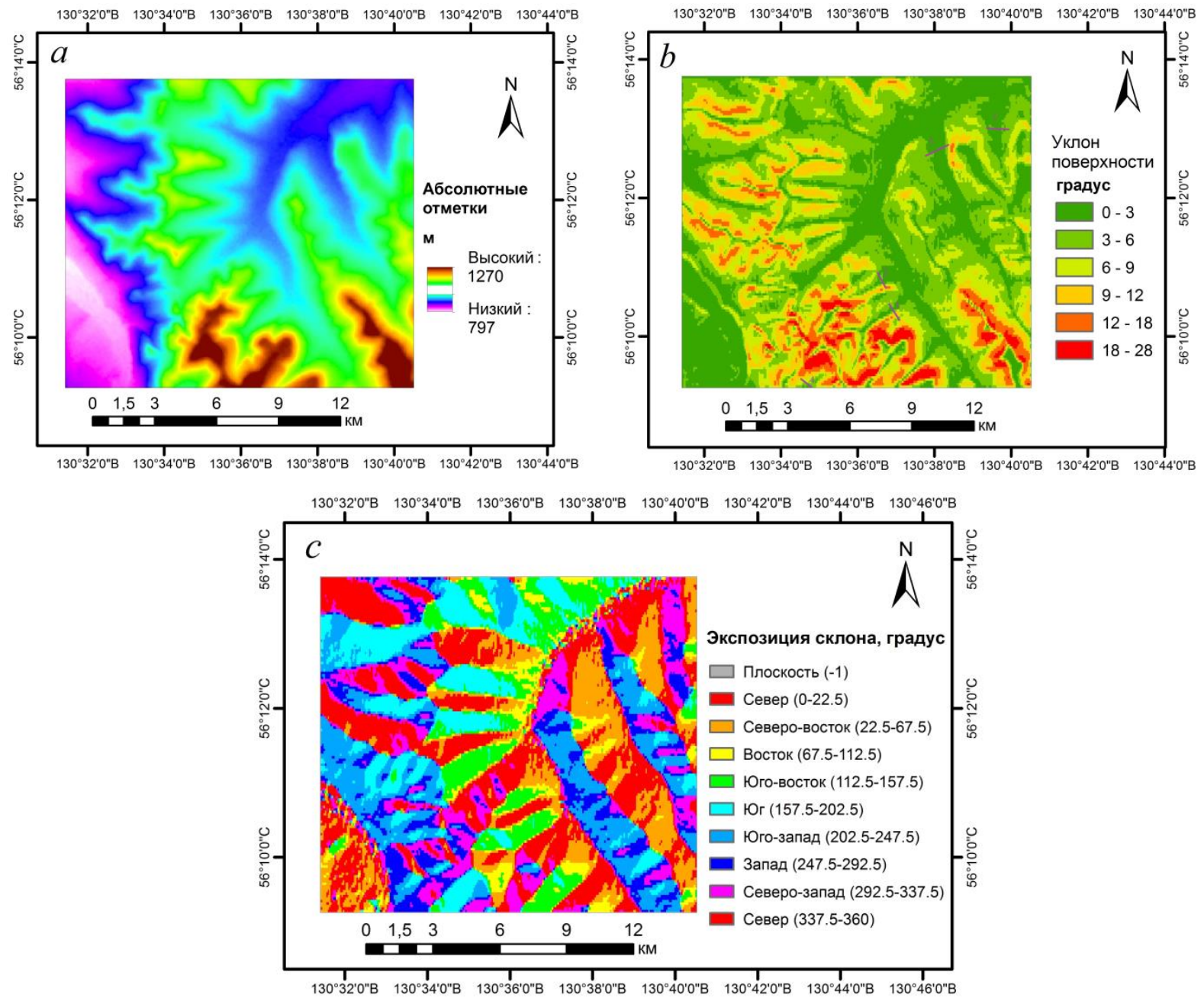

Pис. 2. Характеристика особенностей рельефа района работ

Fig. 2. Characteristics of the features of the study area 


\section{Методика работ}

Изучение уязвимости геологической среды к техногенному загрязнению требует оценки соотношения водопроницаемых и водоупорных пород в разрезе. Использовать такие распространенные методики по оценке защищенности подземных вод, как ВСЕГИНГEO [22], DRASTIC, SINTACS, GOD [23], не представляется возможным из-за спорадического распространения надмерзлотных подземных вод, а также неопределенности конструктивных особенностей дамб-накопителей на момент предпроектного изучения территории. Из имеющихся данных по площадкам, отведенным под пруды-отстойники, следует, что площадки неоднородны по мощности покровных отложений, их строению и фильтрационным характеристикам. Анализ и систематизация данных методом последовательного инженерно-геологического районирования площадок размещения прудовотстойников позволили выделить участки, обладающие определенным набором показателей, оценивающих грунтовую толщу как естественный противофильтрационный барьер.

\section{Результаты}

Оценка инженерно-геологических условий послужила основой для составления карты районирования по степени уязвимости геологической среды к техногенному загрязнению (рис. 3). Работы выполнены автором единолично в ТПУ весной 2019 г. с помощью программ MS Excel и Surfer. Вначале в таблицу MS Excel были занесены данные о местоположении скважин (по строкам), их абсолютных отметках, номерах вскрытых скважинами инженерногеологических элементов, их мощности, глубинах залегания кровли скальных грунтов, кровли многолетнемерзлых пород и уровня подземных вод (по столбцам). Далее для каждой скважины рассчитано приблизительное время инфильтрации загрязняющего фронта до уровня грунтовых вод. Расчет производился согласно методике, разработанной В.М. Гольдбергом [22], с учетом мощности слабопроницаемых пород, коэффициента фильтрации, эффективной пористости пород и напора в хвостохранилище, принятого равным единице. Анализ полученных значений времени инфильтрации и имеющихся публикаций позволил выделить четыре категории по уязвимости, которые также были добавлены к данным по каждой скважине. Следующим шагом стало проставление по каждой скважине - к какому району, подрайону, участку относится ее местоположение. Этот анализ позволил оконтурить в Surfer зоны с разной уязвимостью, обозначенные на карте штриховкой.

При типологическом районировании самые крупные подразделения (районы) выделялись по величине мощности покровных пород: А - при мощности до 2,0 м; Б - от 2,0 до 5,0 м; В - от 5,0 до 10,0 м и Г - при мощности более $10,0 \mathrm{M}$.

Внутри районов выделены подрайоны по величине коэффициента фильтрации (по ГОСТ 25100): a) слабоводопроницаемые с коэффициентом фильтрации менее 0,3 м/сут;

б) водопроницаемые с коэффициентом фильтрации в интервале 0,3-3,0 м/сут;

в) сильноводопроницаемые с коэффициентом фильтрации от 3,0 до $30 \mathrm{M} / \mathrm{cyт}$.

Выделенные подрайоны, в свою очередь, подразделялись на участки по литологическому составу грунтовой толщи, физико-механическим свойствам выделенных инженерно-геологических элементов (ИГЭ): 1, 2, 4, 7, 9, 11, 13 [40].

Класс участка на карте обозначается тремя символами: первый символ - заглавная русская буква, соответствующая району, второй - строчная буква русского алфавита, соответствующая подрайону, третий символ - номер инженерно-геологического элемента.

По условиям уязвимости геологической среды к техногенному загрязнению выделяются четыре категории:

I категория характеризуется как сильно уязвимые территории. К данной категории относятся участки, сложенные с поверхности элювиально-делювиальным дресвяным грунтом с супесчаным заполнителем до 31-41 \% (ИГЭ-7), мощностью до 5,9 м; а также аллювиальными галечниковыми грунтами с супесчаным заполнителем (ИГЭ-13) и песками гравелистыми (ИГЭ-11), мощностью 2,5-5,9 м, подстилаемые песчаниками и алевролитами сильновыветрелыми «рухляками» нерюнгриканской свиты (участки А-б-7, Б-б7, Б-б-13, В-в-11). Время продвижения фронта загрязнения на таких участках составляет менее 5 суток.

II категория - средне уязвимые территории. К данной категории относятся участки (А-б-9, Б-б-2, Б-б-9, В-б-7, В-б-13, Г-б-7, Г-б-13), сложенные с поверхности супесями гравелистыми (ИГЭ-9), суглинками с дресвой песчаников от 2 до $18 \%$, мощностью от 2,9 до 4 м. Эти отложения подстилаются аллювиальными крупнообломочными грунтами мощностью до 2,5 м, залегающими на песчаниках, алевролитах малопрочных и средней прочности. Время продвижения фронта загрязнения на таких участках составляет от 5 до 10 суток.

III категория - слабо уязвимые территории. К данной категории относятся участки, сложенные с поверхности торфом среднеразложившимся (ИГЭ-1), заторфованными суглинками с включениями дресвы мелкозернистых песчаников (ИГЭ-2), супесью с дресвой от 1 до $24 \%$ (ИГЭ-4), мощностью до 4,6 м. Грунты подстилаются верхнеюрскими песчаниками, алевролитами прочными и средней прочности (А-а-4, А-б-1, Б-а-4, Б-б-1, В-а-4, В-б-1, В-б-2). Время продвижения фронта загрязнения составляет 10-15 суток.

IV категория - незначительно уязвимые территории (участки Г-а-4, Г-б-1, Г-б-9). К данной категории относятся участки, сложенные с поверхности в основном глинистыми грунтами мощностью свыше 15 м (ИГЭ-4), подстилаемые верхнеюрскими песчаниками, алевролитами прочными и средней прочности. Время продвижения фронта загрязнения составляет более 15 суток. 

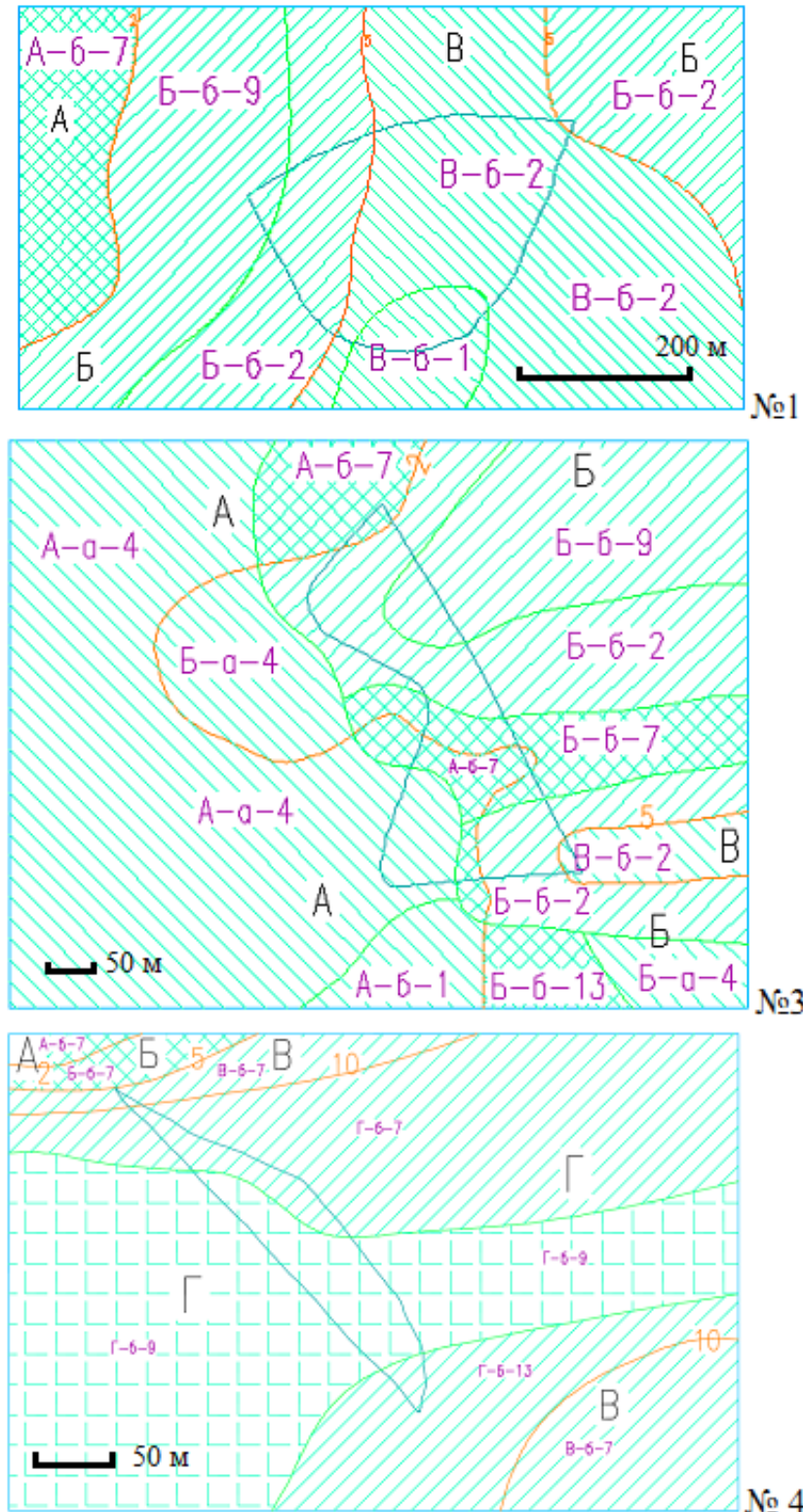
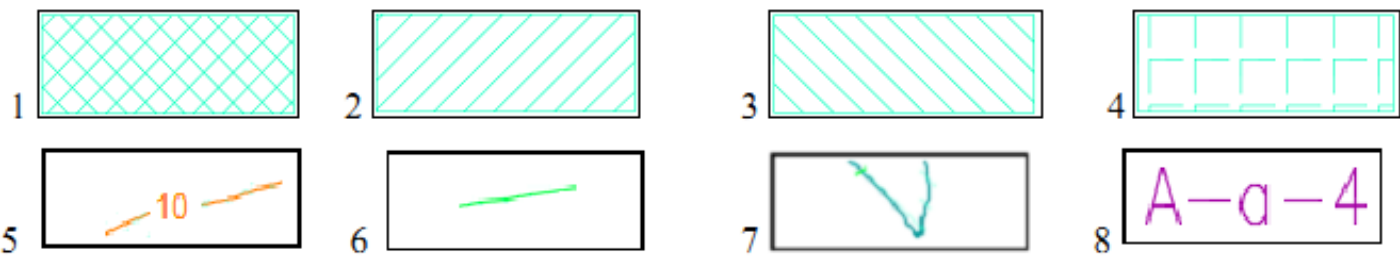
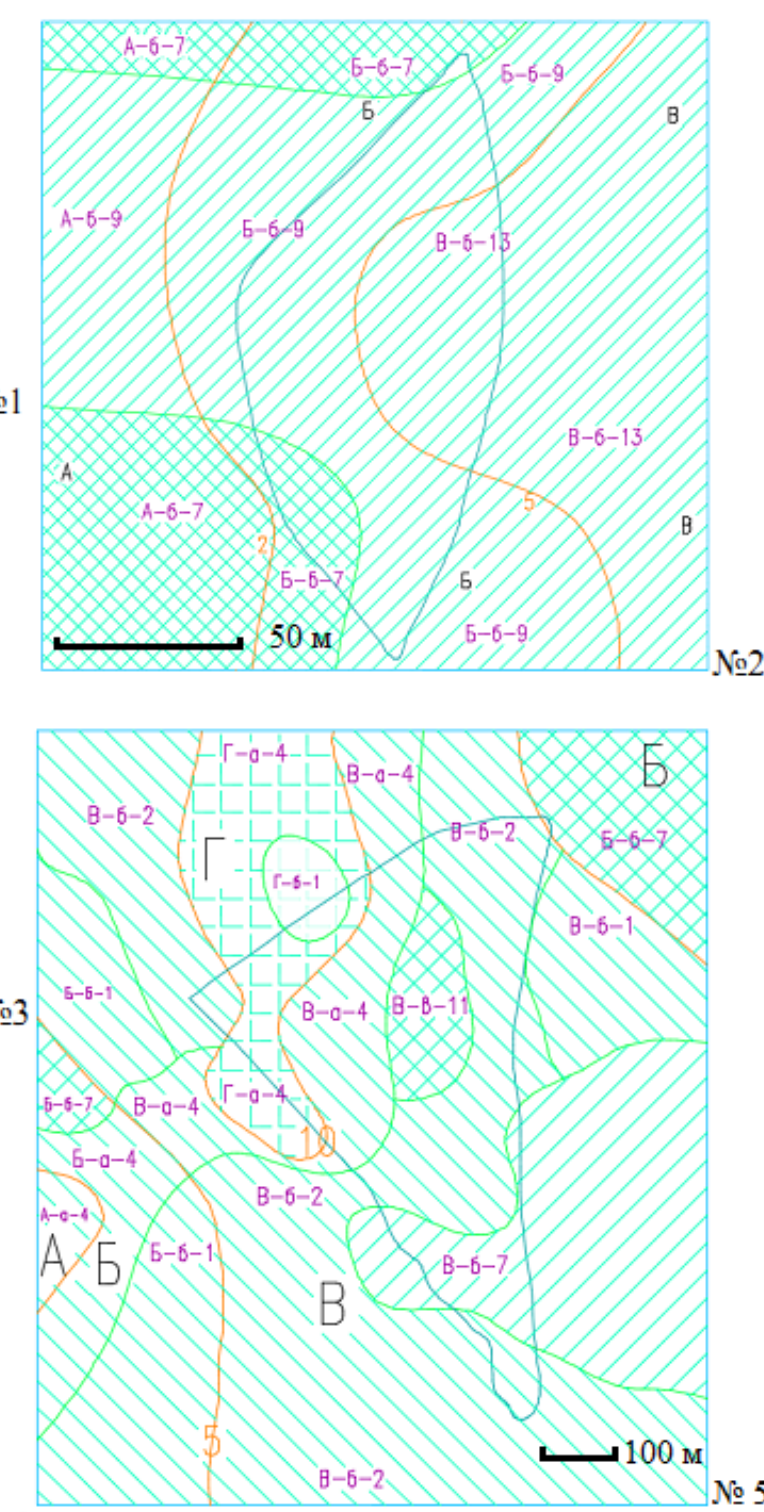

№ 4

Рис. 3. Карта типологического инженерно-геологического районирования площадок размещения прудовотстойников по степени уязвимости геологической среды к техногенному загрязнению. Категории участков: 1 - сильно уязвимые; 2 - средне уязвимые; 3 - слабо уязвимые; 4 - незначительно уязвимые; другие обозначения: 5 - гранищь районов по глубине залегания кровли скальных пород; 6 - гранищы участков, 7 - гранищь проектируемых прудов отстойников; 8 - класс участка

Fig. 3. Map of typological engineering and geological zoning of sites for settling ponds by the degree of vulnerability of the geological environment to anthropogenic pollution. Site categories: 1 - highly vulnerable; 2 - moderate vulnerable; 3 -low vulnerable; 4 -negligible vulnerable; other designations: 5 - boundaries of areas based on the depth of the rock roof; 6 - boundaries of sites, 7 - boundaries of projected settling ponds; 8 - site class

\section{Заключение}

В статье приведена инженерно-геологическая оценка территории площадок прудов-отстойников с точки зрения литологического состава, рельефа, физикомеханических и фильтрационных свойств грунтов. Ав- тором впервые для района Эльгинского угольного месторождения проведена оценка времени инфильтрации загрязняющего фронта и составлена карта районирования по степени уязвимости геологической среды к возможному техногенному загрязнению. Все инфор- 
мационные слои о природной среде вначале обрабатывались в MS Excel, затем объединялись для получения единой инженерно-геологической карты в Surfer. На разработанной карте инженерно-геологического районирования выделены участки с разной степенью уязвимости территории к техногенному загрязнению. Дана характеристика выделенных категорий. Районирование территории может служить основой для принятия обоснованных решений при проектировании ин-

\section{СПИСОК ЛИТЕРАТУРЫ}

1. Афанасиади Э.И., Абатурова И.В., Тарасевич А.В. Опыт инженерно-геологического районирования территории строительства Воронцовского ГОКа с целью рационального использования и охраны геологической среды // Известия Уральского государственного горного университета. - 2001. T. 13. - C. 241-246.

2. Abaturova I.V., Storozhenko I.A., Korolyova I.G. Influence of the components of engineering-geological conditions on the extraction of minerals in the permafrost zone // Mining journal. - 2015. V. 9. - P. 22-27.

3. Грязнов О.Н. Инженерно-геологические условия Урала: науч. моногр. - Екатеринбург: Изд-во Уральского государственного горного университета, 2017. - 240 с.

4. Ганова С.Д. Геоэкологические аспекты создания и функционирования природно-технических систем в условиях криолитозоны Западной Сибири // Известия высших учебных заведений. Геология и разведка. - 2017. - № 5. - С. 58-64.

5. Комплексный метод снижения пылевой и газовой опасностей в угольных шахтах / О.В. Скопинцева, С.Д. Ганова, Н.В. Демин, В.И. Папичев // Горный журнал. - 2018. - № 11. - С. 97-100.

6. Voznesenskii E.A., Latypov A., Zharkova N. Seismic fluidification of soil in the bed of the Kazanskaya Riviera Tower // Soil Mechanics and Foundation Engineering. - 2016. - V. 53 (4). P. 257-263.

7. Николаева Н.А., Пинигин Д.Д. Формирование геотехнических систем при разработке Эльгинского каменноугольного месторождения // Фундаментальные исследования. - 2015. № 8-1. - C. 153-157. URL: http://www.fundamental-research.ru/ ru/article/view?id=38864 (дата обращения: 03.11.2020).

8. Гриб Н.Н., Кузнецов П.Ю. Прогнозирование физикомеханических свойств углевмещающих пород на основе данных геофизических исследований скважин и математического аппарата Марковской нелинейной статистики // Уголь. 2018. - № 1. - С. 68-73.

9. Скоморошко Ю.Н. Оценка устойчивости горных пород в бортах карьеров по результатам геофизических исследований скважин (на примере Эльгинского месторождения): дис. .. канд. техн. наук. - Нерюнгри, 2001. - $181 \mathrm{c}$.

10. Хоютанов Е.А. Обоснование резервов совершенствования процессов управления зольностью угля при разработке сложноструктурных месторождений (на примере Эльгинского месторождения): дис. ... канд. техн. наук. - Якутск, 2016. - 155 с.

11. Бердюгин В.А. Условия отработки «Эльгинского» месторождения каменных углей и планируемые комплексы оборудования для его разработки // Горный информационноаналитический бюллетень. Отдел. выпуск. - 2009. - № 10. C. 373-379.

12. Николаева Н.А., Пинигин Д.Д. Оценка факторов техногенного воздействия на природную среду Эльгинского угольного комплекса // Современные проблемы науки и образования. 2014. - № 5. URL: www.science-education.ru/119-14545 (дата обращения: 05.11.2020).

13. Трофимов В.Т., Красилова Н.С. Инженерно-геологические карты. - М.: КДУ, Добросвет, 2018. - 383 с.

14. Cheskidov V.V., Manevich A.I. Engineering and geological support for slope stability monitoring as a part of transport infrastructure construction projects // Mining science and technology. - 2016. - № 1. - C. 50-57.

15. Purgina D.V., Strokova L.A., Kuzevanov K.I. Modeling of changing hydrogeological conditions during construction of pier foundations on the Kama river bank // IOP Conference Series: женерных сооружений, базой для организации мониторинга, экспертизы. Эффективность рассмотренных в работе критериев следует уточнять путем верификации с натурными данными в рамках системы мониторинга.

Исследование выполнено в Томском политехническом университете в рамках программы повышения конкурентоспособности Томского политехнического университета (средства ВИУ).

Earth and Environmental Science. - 2016. - V. 33. - № 012046. URL: http://iopscience.iop.org/article/10.1088/1755-1315/33/1/012046 (дата обращения: 05.11.2020).

16. Строкова Л.А., Ермолаева А.В. Районирование территории по степени опасности оседания земной поверхности при проектировании магистрального газопровода в южной Якутии // Известия Томского политехнического университета. Инжиниринг георесурсов. - 2016. - Т. 327. - № 10. - С. 59-68.

17. Strokova L.A. Modeling of tunneling-induced ground surface movement Scientific and Technical Challenges in the Well Drilling Progress // IOP Conf. Series: Earth and Environmental Science. - 2015. - V. 24. - 012030. URL: http://iopscience. iop.org/1755-1315/24/1/012030 (дата обращения: 05.11.2020)

18. Строкова Л.А., Епифанова Е.А., Коржнева Т.Г. Численный анализ поведения основания опоры моста на старой железнодорожной линии // Известия Томского политехнического университета. Инжиниринг георесурсов. - 2017. - Т. 328. - № 5. C. $125-139$

19. Епифанова Е.А., Строкова Л.А. Оценка деформаций исторического здания в Томске с помощью комплексного подхода, основанного на сочетании наземного лазерного сканирования и конечно-элементного моделирования // Известия Томского политехнического университета. Инжиниринг георесурсов. 2018. - T. 329. - № 5. - C. 27-41.

20. Епифанова Е.А., Строкова Л.А. Анализ деформаций прожекторной мачты при помощи наземного лазерного сканирования и метода конечных элементов // Известия Томского политехнического университета. Инжиниринг георесурсов. 2019. - T. 330. - № 5. - C. 7-17.

21. Strokova L. Recognition of geological processes in permafrost conditions // Bulletin of Engineering Geology and the Environment. - 2019. - V. 78 (8). - P. 5517-5530.

22. Гольдберг В.М. Взаимосвязь загрязнения подземных вод и природной среды. - Л.: Гидрометеоиздат, 1987. - 248 с.

23. Oroji B. Groundwater vulnerability assessment using GIS-based DRASTIC and GOD in the Asadabad plain // Journal of Materials and Environmental Sciences. - 2018. - V. 9 (6). - P. 1809-1816.

24. Influence of coal mining on groundwater resources and countermeasures in Shanbei energy and chemical base / M.S. Zhang, Y. Dong, R.J. Du, X.F. Gu // Earth Science Frontiers. - 2010. - V. 17 (6). - P. 235-246.

25. Effects of coal mining on shallow water resources in semiarid regions: a case study in the Shennan mining area, Shaanxi, China / W. Qiao, W.P. Li, T. Li, J.Y. Chang, Q. Wang // Mine Water Environment. - 2017. - V. 36 (1). - P. 104-113.

26. Wang K., Lin Z.B., Zhang R.D. Impact of phosphate mining and separation of mined materials on the hydrology and water environment of the Huangbai River basin, China // Sci. Total Environment. - 2016. - V. 543. - P. 347-356.

27. Research and development of the mine geological environment evaluation system / W.W. Jia, G.D. Bao, X.W. Wu, S.W. Jiang, C. Zhai // Advanced Materials Research. - 2011. - V. 270. P. $1354-1359$

28. Ullah K.M., Mansourian A. Evaluation of land suitability for urban land-use planning: Case study Dhaka city // Transactions in GIS. - 2016. - V. 20 (1). - P. 20-37.

29. Martínez-Graña A.M., Goy J.L., Zazo C. Engineering geology maps for planning and manegement of natural parks: «Las Batuecas-Sierra de Francia» and «Quilamas» (Central Spanish System, Salamanca, Spain) // Geosciences. - 2013. - V. 1. P. 46-62.

30. Variations in the building site categories in the underground mining region of Doubrava (Czech Republic) for land use 
planning / M. Marschalko, I. Yilmaz, M. Bednárik, K. Kubečka // Engineering Geology. - 2011. - V. 122. - P. 169-178.

31. Economic vulnerability and regional implications of a low carbon emissions future / D.A. Fleming-Muñoz, L. Poruschi, T. Measham, J. Meyers, M Moglia // Australian Journal of Agricultural and Resource Economics. - 2020. - V. 64. - P. 575-604. DOI: $10.1111 / 1467-8489.12356$

32. The multi-risk vulnerability of global coal regions in the context of mine closure / K. Svobodova, J.R. Owen, E. Lebre, M. Edraki, A. Littleboy // Proceedings of the 13th International Conference on Mine Closure / Eds. A.B. Fourie, M. Tibbett. - Perth: Australian Centre for Geomechanics, 2019. - P. 553-562. DOI: doi.org/10.36487/ACG rep/1915 45 Svobodova

33. Gupta P.K., Sharma D. Assessment of hydrological and hydrochemical vulnerability of groundwater in semi-arid region of Rajasthan, India // Sustainable Water Resources Management. 2019. - V. 5. - P. 847-861. URL: https://doi.org/10.1007/s40899018-0260-6 (дата обращения: 05.11.2020).

34. A GIS-based modified DRASTIC approach for geospatial modeling of groundwater vulnerability and pollution risk mapping in Korba district, Central India / S.S. Singha, S. Pasupuleti, S. Singha et al. // Environmental Earth Sciences. - 2020. - V. 78. Article number: 628. DOI: doi.org/10.1007/s12665-019-8640-2

35. Tai X, Xiao W., Tang Y. A quantitative assessment of vulnerability using social-economic-natural compound ecosystem framework in coal mining cities // Journal of Cleaner Production. 2020. - V. 258. - № 120969. DOI: doi.org/10.1016/j.jclepro. 2020.120969

36. Lv X., Xiao W., Zhao Y., Zhang W., Li S., Sun H. Drivers of spatio-temporal ecological vulnerability in an arid, coal mining region in Western China // Ecological Indicators. -2019. - V. 106. No. 105475. doi.org/10.1016/j.ecolind.2019.105475.

37. Mayer A., Smith E.K., Rodriguez J. Concerned about coal: security, dependence, and vulnerability among coal dependent communities in western Colorado // Energy Research \& Social Science. - 2020. - V. 70. - № 101680. DOI: doi.org/10.1016/ j.erss.2020.101680.

38. Gatto A., Busato F. Energy vulnerability around the world: the global energy vulnerability index (GEVI) // Journal of Cleaner Production. - 2020. - V. 253. - № 118691. DOI: doi.org/ 10.1016/j.jclepro.2019.118691.

39. Государственная геологическая карта Российской Федерации. Масштаб 1:1000000 (третье поколение). Серия АлданоЗабайкальская. Лист О-52 - Томмот. Объяснительная записка / А.В. Радьков, А.В. Молчанов, А.В. Терехов, Е.В. Беленко и др. - СПб.: Картографическая фабрика Всероссийского научно-исследовательского геологического института им. А.П. Карпинского (ВСЕГЕИ), 2016. - 276 с.

40. Опыт инженерно-геологического районирования по несущей способности грунтов промплощадки Эльгинского ГОК в Якутии / Л.А. Строкова, С.А. Дмитриева, Н.В. Осьмушкина, А.В. Осьмушкин // Известия Томского политехнического университета. Инжиниринг георесурсов. - 2019. - Т. 330. - № 2. C. $175-185$.

41. Осьмушин А.В., Осьмушкина Н.В. и др. Отчет о производстве инженерно-геологических изысканий на объекте: «Эльгинский горно-обогатительный комплекс. I очередь строительства» на стадии проектная документация. - Нерюнгри: Нерюнгристройизыскания, 2010. - 1314 с

Поступила 24.09.2020 2.

\section{Информация об авторах}

Строкова Л.А., доктор геолого-минералогических наук, профессор отделения геологии Инженерной школы природных ресурсов Национального исследовательского Томского политехнического университета. 
UDK 624.131

\title{
ZONING OF CONSTRUCTION SITES OF THE SETTLING PONDS OF THE ELGA COAL FIELD IN YAKUTIA
}

\author{
Lyudmila A. Strokova, \\ sla@tpu.ru \\ National Research Tomsk Polytechnic University, \\ 30, Lenin avenue, Tomsk, 634050, Russia.
}

The study is relevant due to the rapid growth of mining exploration and production activities in the permafrost regions of Russia over the last forty years. This paper presents the characteristics of the soils of the settling ponds of the Elga coal field in the Republic of Sakha (Yakutia) on vulnerability of the geological environment to contamination. An engineering-geological evaluation is necessary in order to prepare decision making on land planning and land use of the area as well as to ensure smaller negative impact of industrial and infrastructure development on environment and reducing hazards and damage to constructions, people and property.

This study aims to establish the vulnerability of the territory to man-made pollution based on the study of engineering and geological conditions of the sites of settling ponds.

Object of research is the geological environment. The paper considers the main natural components, which influence land use planning and development, such as lithology; topography; seismotectonic; geotechnic; hydrology-hydrogeology and permafrost.

This study includes a brief review of relevant literature, and a summary of information obtained from geological survey company files. All information layers about the natural environment were manipulated and combined to produce uniform engineering geological map. We produced a zoning map of the study area that shows zones with different degree of geological environment vulnerability of contamination: high, moderate, low, negligible vulnerability.

\section{Key words:}

Settling pond, open-pit mining, soil, coal, geological process, physical and mechanical properties, zoning, vulnerability.

The research was carried out at Tomsk Polytechnic University within the program of Tomsk Polytechnic University Competitiveness Enhancement (VIU funds).

\section{REFERENCES}

1. Afanasiadi E.I., Abaturova I.V., Tarasevich A.V. Experience of engineering-geological zoning of the territory of construction of Vorontsov GOK for the purpose of rational use of the geological environment protection. News of the Ural state mining University, 2001, vol. 13, pp. 241-246. In Rus.

2. Abaturova I.V., Storozhenko I.A., Korolyova I.G. Influence of the components of engineering-geological conditions on the extraction of minerals in the permafrost zone. Mining journal, 2015, vol. 9, pp. 22-27. In Rus.

3. Gryaznov O.N. Inzhenerno-geologicheskie usloviya Urala [Engineering-geological conditions of the Urals: scientific monograph]. Ekaterinburg, Ural state mining university Publ., 2017. $240 \mathrm{p}$.

4. Ganova S.D. Geoecological aspects of creation and functioning of natural and technical systems in the conditions of the cryolithozone of Western Siberia. Proceedings of Higher Schools. Geology and exploration, 2017, no. 5, pp. 58-64. In Rus.

5. Scopinzeva O.S., Ganova S.D., Demin N.V., Papichev V. I. Integrated method of dust and gas hazard reduction in coal mines. Mining Journal, 2018, vol. 11, pp. 97-100. In Rus. DOI: 10.17580/gzh.2018.11.18

6. Voznesenskii E.A., Latypov A., Zharkova N. Seismic Fluidification of Soil in the Bed of the Kazanskaya Riviera Tower. Soil Mechanics and Foundation Engineering, 2016, vol. 53, Iss. 4, pp. 257-263.

7. Nikolaeva N.A., Pinigin D.D. Formation of geotechnical systems in the development of Elgin coal Deposit. Fundamental research 2015, no. 8-1, pp. 153-157. In Rus.

8. Grib N.N., Kuznetsov P.Yu. Prediction of physical and mechanical properties of coal-bearing rocks on the basis of well logging data and mathematical apparatus of Markov nonlinear statistics. Ugol (Russian Coal Journal), 2018, no. 1, pp. 68-73. In Rus.

9. Skomoroshko Yu.N. Otsenka ustoychivosti gornykh porod $v$ bortakh karerov po rezultatam geofizicheskikh issledovaniy skvazhin (na primere Elginskogo mestorozhdeniya). Dis. Kand. nauk [Evaluation of rock stability in the sides of the quarries on the basis of geophysical studies of wells (on the example of Elga field). Cand. Diss.]. Neryungri, 2001. $181 \mathrm{p}$.

10. Khoyutanov E.A. Obosnovanie rezervov sovershenstvovanya protsessov upravleniya zolnostyu uglya pri razrabotke slozhnostrukturnykh mestorozhdeniy (na primere Elginskogo mestorozhdeniya). Dis. Kand. nauk [Substantiation of reserves of improving the management of coal ash in development of complex fields (on the example of the Elga field). Cand. Diss]. Yakutsk, 2016. $155 \mathrm{p}$.

11. Berdyugin V.A. Conditions of mining of the Elga coal field and planned complexes of equipment for its development. Mining information Bulletin, 2009, vol. 10, pp. 373-379. In Rus.

12. Nikolaeva N.A., Pinigin D.D. Assessment of factors of technogenic impact on the natural environment of the Elginsky coal complex. Modern problems of science and education, 2014, no. 5. In Rus. Available at: www.science-education.ru/119-14545 (accessed 05 November 2020).

13. Trofimov V.T., Krasilova N.S. Inzhenerno-geologicheskie karty [Engineering-geological maps]. Moscow, KDU, Dobrosvet Publ., $2018.383 \mathrm{p}$.

14. Cheskidov V.V., Manevich A.I. Engineering and geological support for slope stability monitoring as a part of transport infrastructure construction projects. Mining science and technology, 2016, no. 1, pp. 50-57. In Rus.

15. Purgina D.V., Strokova L.A., Kuzevanov K.I. Modeling of changing hydrogeological conditions during construction of pier foundations on the Kama river bank. IOP Conference Series: Earth and Environmental Science, 2016, vol. 33, 01246. Available at: http://iopscience.iop.org/article/10.1088/1755-1315/33/1/012046 (accessed 5 November 2020)

16. Strokova L.A., Ermolaeva A.V. Zoning according to the hazard level of earth surface subsidence when designing the main gas pipeline in south Yakutia. Bulletin of the Tomsk Polytechnic University. Geo Assets Engineering, 2016, vol. 327, no. 10, pp. 59-68. In Rus.

17. Strokova L. A. Modeling of tunneling-induced ground surface movement Scientific and Technical Challenges in the Well Drilling Progress. IOP Conf. Series: Earth and Environmental 
Science, 2015, vol. 24, 012030. Available at: http://iopscience.iop.org/ 1755-1315/24/1/012030 (accessed 5 November 2020)

18. Strokova L.A., Epifanova E.A., Korzhneva T.G. Numerical analysis of bridge foundation behaviour on the old railway line Bulletin of the Tomsk Polytechnic University. Geo Assets Engineering, 2017, vol. 328 (5), pp. 125-139. In Rus.

19. Epifanova E.A., Strokova L.A. Evaluation of deformation of a historic building in Tomsk by an Integrated Approach Based on Terrestrial Laser Scanner and Finite Element Modeling. Bulletin of the Tomsk Polytechnic University, Geo Assets Engineering, 2018, vol. 329 (5), pp. 27-41. In Rus.

20. Epifanova E.A., Strokova L.A. Numerical analysis of deformations of the lighting mast by ground laser scanning and finite elements method. Bulletin of the Tomsk Polytechnic University. Geo Assets Engineering, 2019, vol. 330, no 5, pp. 7-17. In Rus.

21. Strokova L. Recognition of geological processes in permafrost conditions. Bulletin of Engineering Geology and the Environment, 2019, vol. 78 (8), pp 5517-5530.

22. Goldberg V. M. Vzaimosvyaz zagryazneniya podzemnykh vod prirodnoy sredy [The relationship of groundwater pollution and the environment]. Leningrad, Gidrometeoizdat Publ., 1987. 248 p.

23. Oroji B. Groundwater vulnerability assessment using GIS-based DRASTIC and GOD in the Asadabad plain. Journal of Materials and Environmental Sciences, 2018, vol. 9 (6), pp. 1809-1816.

24. Zhang M.S., Dong Y., Du R.J., Gu X.F. Influence of coal mining on groundwater resources and countermeasures in Shanbei energy and chemical base. Earth Science Frontiers, 2010, vol. 17 (6) pp. 235-246.

25. Qiao W., Li W.P., Li T., Chang J.Y., Wang Q. Effects of coal mining on shallow water resources in semiarid regions: a case study in the Shennan mining area, Shaanxi, China. Mine Water Environment, 2017, vol. 36 (1), pp. 104-113.

26. Wang K., Lin Z.B., Zhang R.D. Impact of phosphate mining and separation of mined materials on the hydrology and water environment of the Huangbai River basin, China Sci. Total Environment, 2016, vol. 543, pp. 347-356.

27. Jia W.W., Bao G.D., Wu X.W., Jiang S.W., Zhai C. Research and development of the mine geological environment evaluation system. Advanced Materials Research, 2011, vol. 270, pp. 1354-1359

28. Ullah K.M., Mansourian A. Evaluation of land suitability for urban land-use planning: case study Dhaka city. Transactions in GIS, 2016, vol. 20 (1), pp. 20-37.

29. Martínez-Graña A.M., Goy J.L., Zazo C. Engineering geology maps for planning and manegement of natural parks: «Las Batuecas-Sierra de Francia» and "Quilamas» (Central Spanish System, Salamanca, Spain). Geosciences, 2013, vol. 1, pp. 46-62.

30. Marschalko M., Yilmaz I., Bednárik M., Kubečka K. Variations in the building site categories in the underground mining region of Doubrava (Czech Republic) for land use planning. Engineering Geology, 2011, vol. 122, pp. 169-178.

31. Fleming-Muñoz D.A., Poruschi L., Measham T., Meyers J., Moglia M. Economic vulnerability and regional implications of a low carbon emissions future. Australian Journal of Agricultural and Resource Economics, 2020, vol. 64, pp. 575-604. DOI: $10.1111 / 1467-8489.12356$
32. Svobodova K., Owen J.R., Lebre E., Edraki M., Littleboy A. The multi-risk vulnerability of global coal regions in the context of mine closure. Proceedings of the $13^{\text {th }}$ International Conference on Mine Closure. Eds. A.B. Fourie, M. Tibbett. Perth, Australian Centre for Geomechanics, 2019. pp. 553-562. DOI: doi.org/10.36487/ACG_rep/1915_45_Svobodova

33. Gupta P.K., Sharma D. Assessment of hydrological and hydrochemical vulnerability of groundwater in semi-arid region of Rajasthan, India. Sustainable Water Resources Management, 2019, vol. 5, pp. 847-861. Available at: https://doi.org/10.1007/s40899018-0260-6 (accessed 5 November 2020).

34. Singha S.S., Pasupuleti S., Singha S. A GIS-based modified DRASTIC approach for geospatial modeling of groundwater vulnerability and pollution risk mapping in Korba district, Central India. Environmental Earth Sciences, 2019, vol. 78, no. 628. DOI: doi.org/10.1007/s12665-019-8640-2

35. Tai X, Xiao W., Tang Y. A quantitative assessment of vulnerability using social-economic-natural compound ecosystem framework in coal mining cities. Journal of Cleaner Production, 2020, vol. 258, no. 120969. DOI: doi.org/10.1016/j.jclepro.2020. 120969

36. Lv X., Xiao W., Zhao Y., Zhang W., Li S., Sun H. Drivers of spatio-temporal ecological vulnerability in an arid, coal mining region in Western China. Ecological Indicators, 2019, vol. 106, no. 105475. DOI: doi.org/10.1016/j.ecolind.2019.105475.

37. Mayer A., Smith E.K., Rodriguez J. Concerned about coal: security, dependence, and vulnerability among coal dependent communities in western Colorado. Energy Research \& Social Science, 2020, vol. 70, no. 101680. DOI: doi.org/10.1016/ j.erss.2020. 101680

38. Gatto A., Busato F. Energy vulnerability around the world: The global energy vulnerability index (GEVI). Journal of Cleaner Production, 2020, vol. 253, no. 118691. DOI: doi.org/10.1016/ j.jclepro.2019.118691.

39. Radkov A.V., Molchanov A.V., Terekhov A.V., Belenko E.V. Gosudarstvennaya geologicheskaya karta Rossiyskoy Federatsii. Masshtab 1:1000000 (trete pokolenie). Seriya AldanoZabaykalskaya. List O-52 - Tommot [The state geological map of the Russian Federation. Scale 1:1000000 (third generation). Series Aldano-Zabaikalskaya. Sheet O-52-Tommot. Explanatory note. StPetersburg, Map factory VSEGEI Publ., 2016. $276 \mathrm{p}$

40. Strokova L.A., Dmitrieva S.A. Osmushkina N.V., Osmushkin A.V. Experience of engineering-geological zoning on bearing capacity of soils of the industrial site of Elga coal-preparation plant in Yakutia. Bulletin of the Tomsk Polytechnic University. Geo Assets Engineering, 2019, vol. 330, no. 2, pp. 175-185. In Rus.

41. Osmushkin A.V., Osmushkina N.V. Otchet ob inzhenernogeologicheskikh izyskaniyakh na obekte: «Elginsky gornoobogatitelny kompleks. I ochered stroitelstva» nf stadia proektnaya dokumentatsiya [Report on the production of engineering-geological surveys at the facility: «Elga mining and processing complex. I stage of construction». The stage of Project Documentation]. Neryungri, Neryungristroyizyskaniya Publ., 2010 $1314 \mathrm{p}$.

Received: 24 September 2020.

Information about the authors

Lyudmila A. Strokova, Dr. Sc., professor, National Research Tomsk Polytechnic University. 